\title{
Universiteit
}

Leiden

The Netherlands

\section{Negotiating meaning at a distance: peer feedback in electronic} learning translation environments

Lisaité, D.; Vandepitte, S.; Maylath, B.; Mousten, B.; Valdez, S.; Castel-Branco, M.; ... ; Lewandowska-Tomaszczyk, B.

\section{Citation}

Lisaité, D., Vandepitte, S., Maylath, B., Mousten, B., Valdez, S., Castel-Branco, M., \& Minacori, P. (2016). Negotiating meaning at a distance: peer feedback in electronic learning translation environments. In M. Thelen, G. van Egdom, D. Verbeeck, L. Bogucki, \& B. Lewandowska-Tomaszczyk (Eds.), Lodz Studies in Language (pp. 99-116). Frankfurt an Main: Peter Lang Verlag. Retrieved from https://hdl.handle.net/1887/3238742

Version: $\quad$ Accepted Manuscript

License: $\quad$ Leiden University Non-exclusive license

Downloaded from: https://hdl.handle.net/1887/3238742

Note: To cite this publication please use the final published version (if applicable). 


\section{Negotiating meaning at a distance:}

\section{Peer feedback in electronic learning translation environments}

Donata LISAITÉ, Sonia VANDEPITTE, Bruce MAYLATH, Birthe MOUSTEN, Susana VALDEZ, Maria CASTEL-BRANCO \& Patricia MINACORI

Donata LISAITE் \& Sonia VANDEPITTE

Ghent University

Department of Translation, Interpreting and Communication

Groot-Brittanniëlaan 45, B-9000 Ghent, Belgium

Bruce MAYLATH

North Dakota State University

Department of English

Fargo, North Dakota 58108-6050, USA

Birthe MOUSTEN

Aarhus University

Departament of Business Communication

Jens Chr. Skous Vej. 4, 8000 Aarhus C, Denmark

Susana VALDEZ

Univ. Nova/CEAUL

Departamento de Línguas, Culturas e Literaturas Modernas Faculdade de Ciências Sociais e Humanas - FCSH/NOVA

Av. de Berna, 26 C, 1069-061 Lisboa, Portugal

Maria da Conceição CASTEL-BRANCO

Departamento de Línguas, Culturas e Literaturas Modernas

CETAPS (Centre for English, Translation and Anglo-Portuguese Studies)

Faculdade de Ciências Sociais e Humanas

Universidade Nova de Lisboa

Avenida de Berna, 26-C / 1069-061 Lisboa, Portugal

Patricia MINACORI

Université Paris Diderot

UFR EILA

Bâtiment Olympe de Gouges, 8 Place Ricoeur, 75205 Paris Cedex 13, France 


\begin{abstract}
Recent research has contributed to an understanding of the positive impact that peer feedback has on student learning, but there is a lack of experimental studies that focus on how peer feedback affects student translation competences. Our study investigates whether the latter are enhanced in the Trans-Atlantic \& Pacific Project (TAPP) with an experiment that included the explicit practice of student peer feedback competences and the negotiation of meaning among peers. Students - whether writing, translating or usability testing - collaborated online both within their own university peer group and with a partner university. The results of this intervention, however, suggest no clear tendencies or relation between peer feedback and meaning-related translation competences.
\end{abstract}

\title{
Keywords
}

peer feedback - online collaborative learning - translation training- negotiation of meaning

\section{Peer feedback: theoretical rationale}

In modern education, peer feedback has been increasingly employed as a learning, instructional and assessment strategy. The notion of peers evaluating each other's work actually goes back to several theoretical schools of thought, in particular, Vygotsky's Zone of Proximal Development theory (1978) and his sociocultural theory (1986), which claim that individuals usually learn in the company of other people and that learning, therefore, 'presupposes a specific social nature' $(1978,34)$.

There are several reasons for the recent increase in interest in peer feedback. First, it has been claimed that peerto-peer interaction facilitates the construction of knowledge, enhances learner autonomy and acquisition of various skills (Tudge 1990; Wells 1999; Swain et al. 2002). According to Swain et al., for instance, learners often collaborate to 'solve linguistic problems and/or co-construct language or knowledge about language' $(2002,172)$ and as such they enter a so-called 'collaborative dialogue'. In addition, research has shown that peer feedback not only encourages learners to act autonomously by thinking critically: it also enables them to acquire both domainspecific skills (e.g. writing) and transferable skills (e.g. an ability to work in a team, acknowledge and discuss different points of view, or consider the details of feedback provided by a fellow student) (Berg 1999; Paulus 1999; Tang \& Tithecott 1999). This can also be linked to changing working conditions in society: for example, in order to be successful in their careers, employees need to demonstrate twenty-first century skills such as flexibility and higher order skills (e.g. problem solving, critical thinking, lifelong learning, intercultural communication) (Scardamalia 2001; Starke-Meyerring 2008; van Zundert et al. 2010).

Considering the fact that all the above-listed aspects underscore the co-constructional and interpersonal nature of peer feedback activities, it follows that engaging in peer feedback activities may significantly affect patterns in the generation of meaning by individuals. While research into peer feedback has been conducted in a great number of fields, the question can be asked whether peer feedback activities are a useful tool for negotiating meaning in cross-cultural and interdisciplinary writing and, in particular, in a translation setting. 
Collaborative learning for translation has recently been pointed out as useful for translation training (Babych et al. 2012; Gambier 2012; Desjardins 2011; Huertas Barros 2011; O’Brien 2011; Risku \& Dickinson 2009; Zili 2009; Kenny 2008; Muñoz Martín 2007; Pavlović 2007; González Davies 2004; Kiraly 2000). In addition, Babych et al. emphasised that both commercial and non-commercial translation are becoming increasingly reliant on collaborative activities (2012). Therefore, translation trainees will benefit from practising this learning model as early as possible.

In particular, Kiraly stressed the need for a constructivist approach towards translator education by emphasizing the impact of collaborative activities on the generation of meaning: 'individuals (...) create or construct meanings through participation in the interpersonal, inter-subjective interaction' (Kiraly 2000: 50-51). In addition, Kiraly states that translators enhance their competences by joining and working together. Relying on these underlying assumptions, Kilary implemented a two-year qualitative action study in which students collaborated on a translation project and three types of data were collected: questionnaires filled out by the students, verbal data collected using tape recorders and direct observation (for example of non-verbal behaviour). The results revealed that the students were highly motivated, worked very efficiently and reported having gained a substantial insight into both translation and collaborative work.

While considerable research has been conducted to highlight the importance of and the need for collaborative translation, there is a lack of empirical studies that show the impact of peer feedback on translation competences.

\section{$3 \quad$ Terminology}

The terms that are used to refer to assessing and commenting a colleague's work are numerous. For purposes of clarity, here are explanations of our own understanding of some of the recurring terms, which are used within a translation context that aims to adhere to industry norms EN-15038 and ISO 17100:2015:

- Peer collaboration: students working with each other towards a common goal (activities involve, but are not limited to, exchanging documents, assisting each other etc.).

- Peer interaction: students interacting with each other, i.e. part of peer collaboration where they are actually communicating with each other (at a distance or in person).

- Peer feedback: students observing other students' work. In the context of our study, this involved students reading each other's translations and giving comments for improvement.

- Peer revision: students examining the translation for suitability in terms of its adequacy in representing the source text message in the target language.

- Peer review: students proofreading the translation for acceptability in terms of its target language.

- Peer assessment: students reading other students' work and giving it a mark. 
The existing body of research into peer-to-peer activities is substantial; however, some researchers warn that it should not be blindly trusted. van Zundert et al. $(2010,270)$ point out that it is 'impossible to make claims about what constitutes effective PA [peer assessment]'. Furthermore, Strijbos and Sluijsmans (2010) state that the ambiguity and diversity of peer assessment practices make it difficult to see how peer assessment actually facilitates learning. One way to disambiguate the situation could be by explicitly training students to peer assess each other's work. Importantly, peer feedback training is also reported to contribute to the success of peer feedback activities (Finn and Garner 2011, 445). Such training serves a two-fold purpose: first, students learn to convey constructive feedback and, secondly, research into L2 feedback has revealed that without prior training L2 revisers tend not to address higher-order - or meaning-related - problems such as content and structure (Leki 1990; Mangelsdorf and Schlumberger 1992; Flynn 1982). Further positive effects of peer feedback training on the quality of students' writing tasks are discussed in Min $(2005,2006)$ and Van Steendam et al. (2010).

5

Pilot study

Our own experiment involved three translation tests - a Pre-test (1T), a Mid-test (2T) and a Post-test (TT) - spread out over a period of seven weeks (Appendix A) by 29 students of the Master course 'English: General Translation Practice' at Ghent University Autumn 2013. In between the tests, participants were familiarized with and did peer feedback activities within the Trans-Atlantic and Pacific Project (TAPP), described in more detail elsewhere (Humbley et al. 2005; Vandepitte et al. 2015). They carried out the usual project activities except for the fact that half of the class performed them in the former half of that period, while the other half of the class performed them in the latter half of the period. Throughout these activities, participants formed triplets of students to translate a popular science article that was drafted by a small team of scientific writing students from North Dakota State University at Fargo.

The cohort ( $\mathrm{n}=29$ ) was divided into two groups: Group A consisted of eighteen participants and Group B included eleven participants. Four other students participated in only one or two out of three tests and their data were excluded from the analysis.

Students' feedback activities could be either of the following two kinds. First, Ghent University students were able to contact their source text writers in Fargo and ask them for clarification of certain source text passages. Secondly, Ghent students themselves were organized in small teams of one translator, one reviser and one reviewer. Each student was also registered in three teams and therefore played each role once, participating in the translation of three different texts or text passages.

To enhance comparability of the test data, three slightly modified versions of a fragment adapted from Colfer Eoin's children's book Artemis Fowl: The Lost Colony (see Appendix B) were translated in the Pre-, Mid- and Post-tests. This text allows for testing the students' formal linguistic and meaning-related translation problem solving skills and includes a set of ten diverse translation difficulties that students had to address. Formal linguistic items included six phrases that required translation problem solving skills related to reference, punctuation, numerals, noun phrase structure and completeness, while four meaning-related items involved considerations about the proper use of modality, figures of speech, register and cultural reference. These items remained unchanged in the three tests.

Participants' translation competence was solely measured in terms of the (in)correct translation of the ten preselected items. For each correctly translated item they received one point. All students' scores were first individually determined by two assessors (two authors) and then discussed with the purpose to find agreement on scores allowing for a difference of only one point between the two scores for one participant. 
The data analysis focusses on how the participants' scores developed with respect to the different sets of evaluation items, i.e. formal linguistic items versus meaning-related items on the evaluation criteria. The main question in our analysis was therefore to examine whether any learning differences were found between the two sets of items. If feedback activities help students think critically (Berg 1999), it is logical to expect them to become better at the meaning-related items.

\subsection{Participant score development for formal linguistic items}

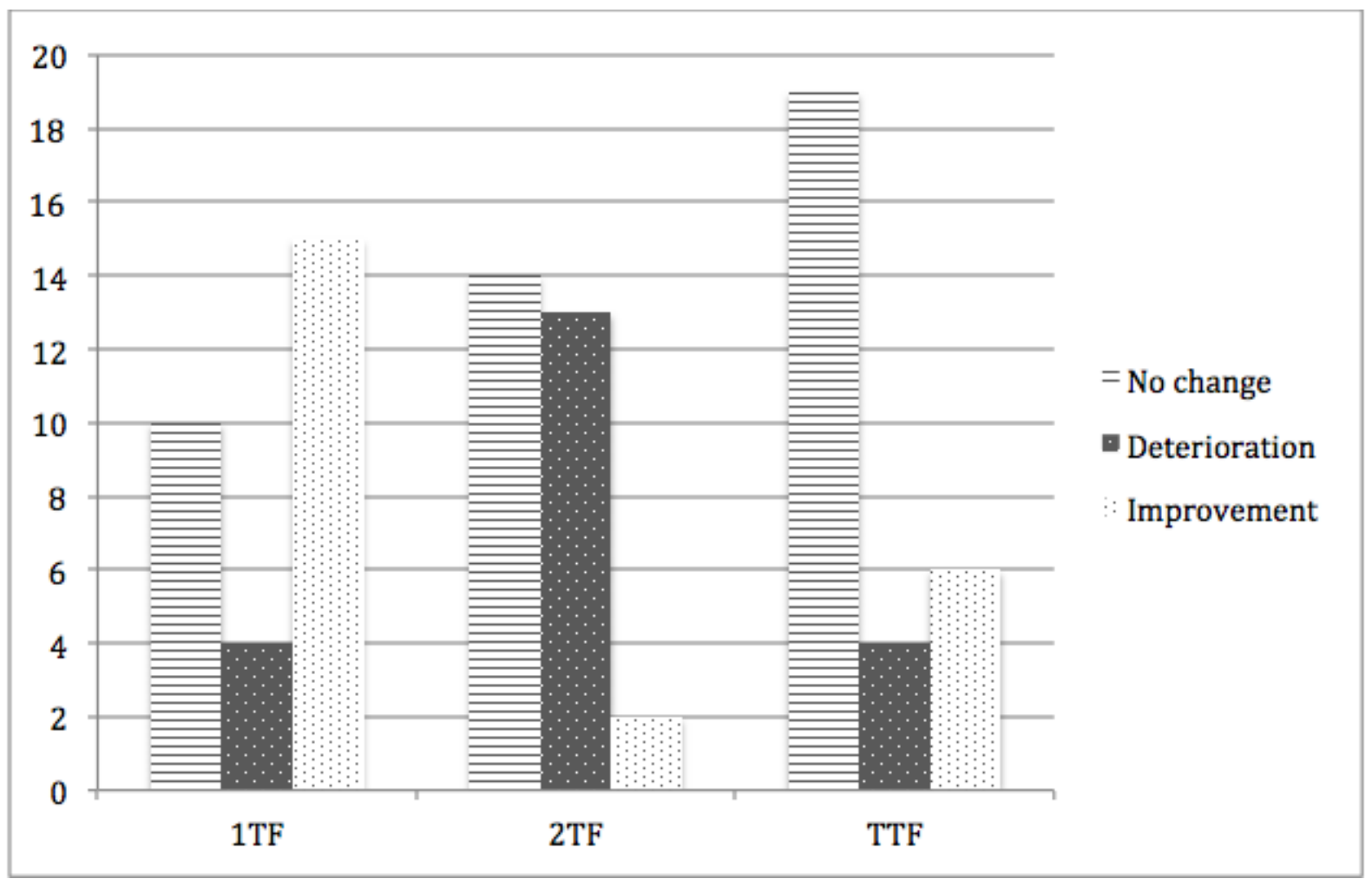

Figure 1. Participant score development over the three tests: comparison of Pre-test to Mid-test (1T), Mid-test to Post-test (2T) and Post-test to Pre-test (TT) for six evaluation items. Letter F refers to formal linguistic translation competences. $(n=29)$

On the basis of the score development analysis using the six pre-selected formal linguistic evaluation items, the results visualised in Figure 1 emerged. They show that the pattern produced by taking only formal linguistic evaluation items highlights the increasingly dominant No change bar: the comparison between the Mid-test and Pre-test (1TF) shows that 10 participants (34.4\%) received the same scores; however, their number grew when comparing the results of the Post-test to the Mid-test (2TF) ( $\mathrm{n}=14,48.27 \%)$ and was the highest $(\mathrm{n}=19,65.5 \%)$ when comparing the Post-test to the Pre-test (TTF).

As far as improvement in the results is concerned, the most significant number of the participants received better results in the Mid-test (1TF) ( $\mathrm{n}=14,48.27 \%)$. However, improvement decreased substantially in the Post-test (2TF) $(n=2,6.89 \%)$ and increased slightly when comparing the results in the Post-test to those in the Pre-test (TTF) $(\mathrm{n}=6,20.68 \%)$.

In addition, score deterioration is also notable, especially when comparing the results in the Post-test to those in the Mid-test (2TF) (n=13, 44.82\%). The comparison of the results in the Mid-test to those in the Pre-test (2TF) 
reveals that four participants (13.79\%) received lower scores in the Mid-test. The same number of participants scored lower in the Post-test than in the Pre-test.

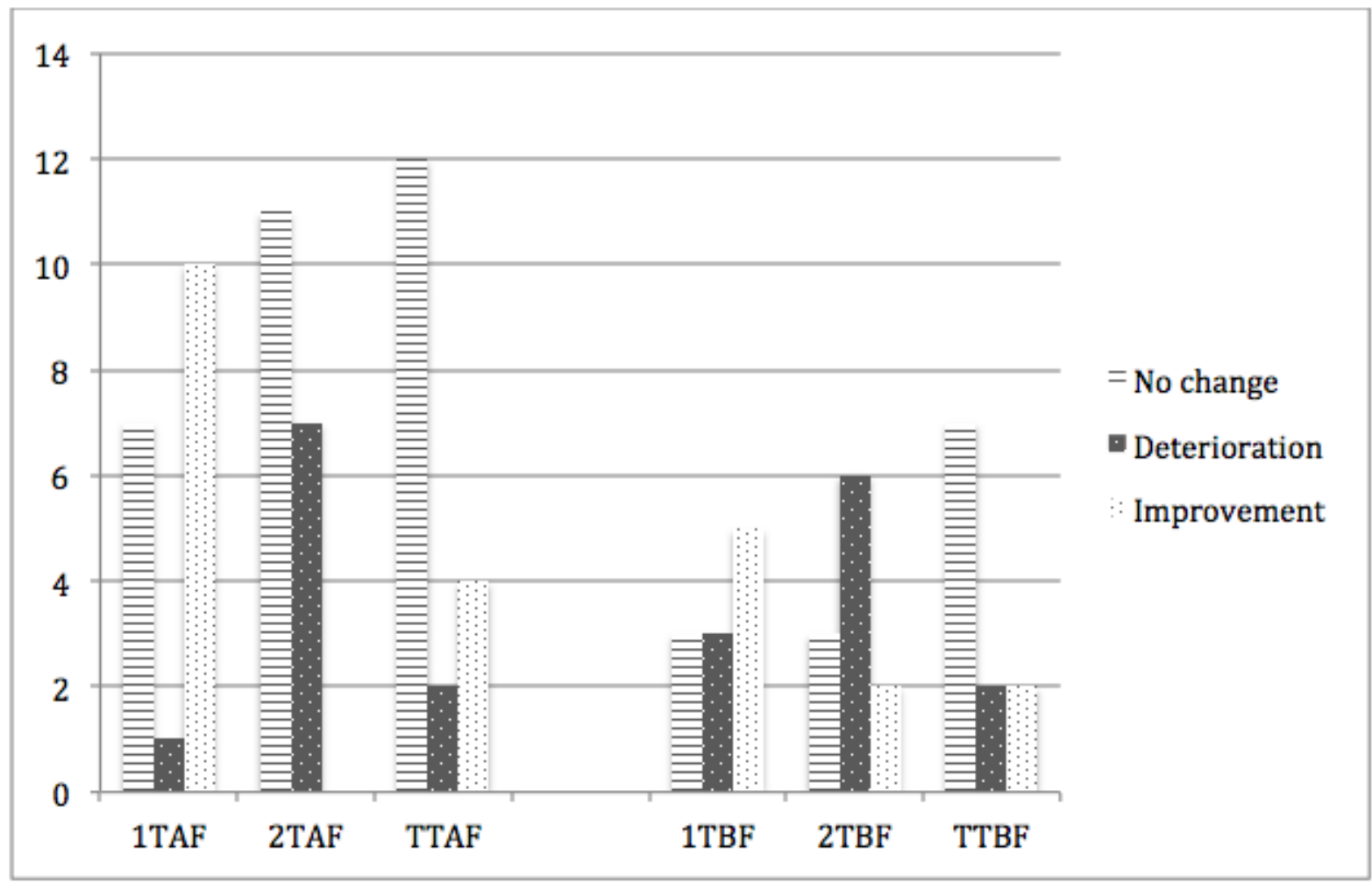

Figure 2. Groups A and B: Participant score development over the three tests: comparison of Pre-test to Mid-test (1T), Mid-test to Post-test (2T) and Post-test to Pre-test (TT) for six evaluation items. Letters A and B represent Groups $A$ and $B$ respectively. Letter $F$ refers to formal linguistic translation competences. (Group A: $n=18$, Group B: $n=11$ )

Figure 2 shows the separate score development patterns for both groups. Group A (left) reveals the same pattern as the entire cohort: the comparison between the Mid-test and Pre-test (1TAF) shows that more than half of the participants scored higher in the Mid-test $(n=10,55.55 \%)$; however, this tendency was not retained when comparing the results of the Post-test to those of the Mid-test (2TAF): no participants scored higher in the Posttest and more than one third of the participants $(n=7,38.88 \%)$ scored lower than in the Mid-test. The comparison between the Post-test and the Pre-test (TTAF) shows that the situation changed again and there was a small number of people who improved upon their scores $(n=4,22.22 \%)$. However, the majority of the participants did not see their results change $(n=12,66.66 \%)$ and the remaining $11.11 \%(n=2)$ received lower scores.

The situation in Group B is somewhat different. Even though Group B is smaller than Group A, the number of people whose results deteriorated in the Mid-test with respect to the Pre-test (1TBF) is higher $(n=3)$ than in Group A $(n=1)$. The comparison between the Post-test and Mid-test (2TBF) shows that while there were some students who improved upon their results in the Post-test $(n=2,18.18 \%)$, more than half of the participants $(n=6,54.54 \%)$ scored lower. The comparison between the Post-test and the Pre-test (TTBF) again reiterates the tendency seen in Group A: the most significant proportion of the participants $(n=7,63.63 \%)$ received the same scores both in the Post-test and the Pre-test.

The analysis of the score development of formal linguistic evaluation items suggests a clear tendency of a steadily growing number of the participants whose results remained unaffected. This is true of both individual groups and the entire cohort. While significant proportions of the participants in both groups show improved results in the comparison between the Mid-test and Pre-test (1TAF and 1TBF) and worse results in the Post-test than in the 
Mid-test (2TAF and 2TBF), the highest numbers of the participants ultimately received the same results in the Pre-test and the Post-test (TTAF and TTBF). This pattern implies that no lasting changes can be seen in the scores when evaluating the pre-selected formal linguistic items.

In terms of score development and the timing of peer feedback activities, it is interesting to observe again that whereas Group A shows a surge of improved scores in the Mid-test after engaging in the peer feedback activities (1TAF), the opposite is true of Group B (2TBF) as their scores received at the Post-test, after doing peer feedback activities, are worse than in the Mid-test. In spite of Group B's overall better performance at all tests, it seems to score exceptionally badly at translating formal linguistic items, especially immediately after its peer feedback activities, when it proves to present the only instance where the number of students performing worse compared to previous tests is higher than those of students remaining stable, let alone performing better. We cannot account for these findings.

\subsection{Participant score development for meaning-related items}

Figure 3 presents the analysis of score development in terms of meaning-related items. The results show that the majority of the participants' scores $(n=22,75.86 \%)$ were either lower than $(n=11)$ or the same as $(n=11)$ in the Mid-test compared to the Pre-test (1TM). This tendency changes, however, when the results of the Post-test are compared to those of the Mid-test (2TM): the vast majority of the students scored the same $(\mathrm{n}=21,72.41 \%)$, while equal proportions of the remaining students $(27.6 \%, \mathrm{n}=8)$ scored either higher or lower. The ultimate comparison of the Post-test with the Pre-test results (TTM) shows that the number of students who received higher $(\mathrm{n}=7$, $24.13 \%)$ or lower $(n=6,20.68 \%)$ scores increased, but the most significant part of the participants $(n=16,55.17 \%)$ did not see their scores change.

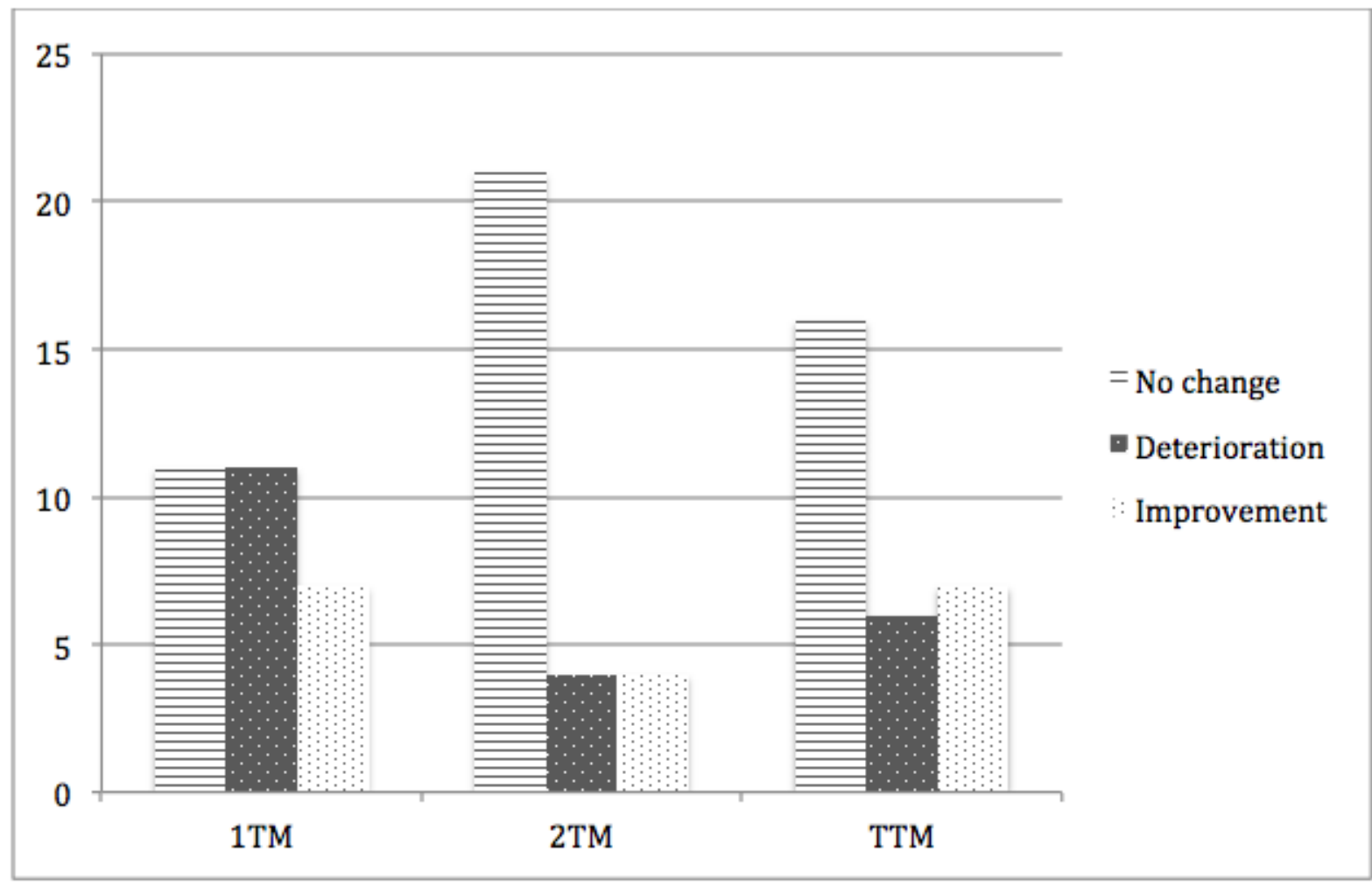

Figure 3. Participant score development over the three tests: comparison of Pre-test to Mid-test (1T), Mid-test to Post-test (2T) and Post-test to Pre-test (TT) for four evaluation items. Letter $M$ refers to meaning-related translation competences. (Groups $A$ and $B: n=29$ ) 


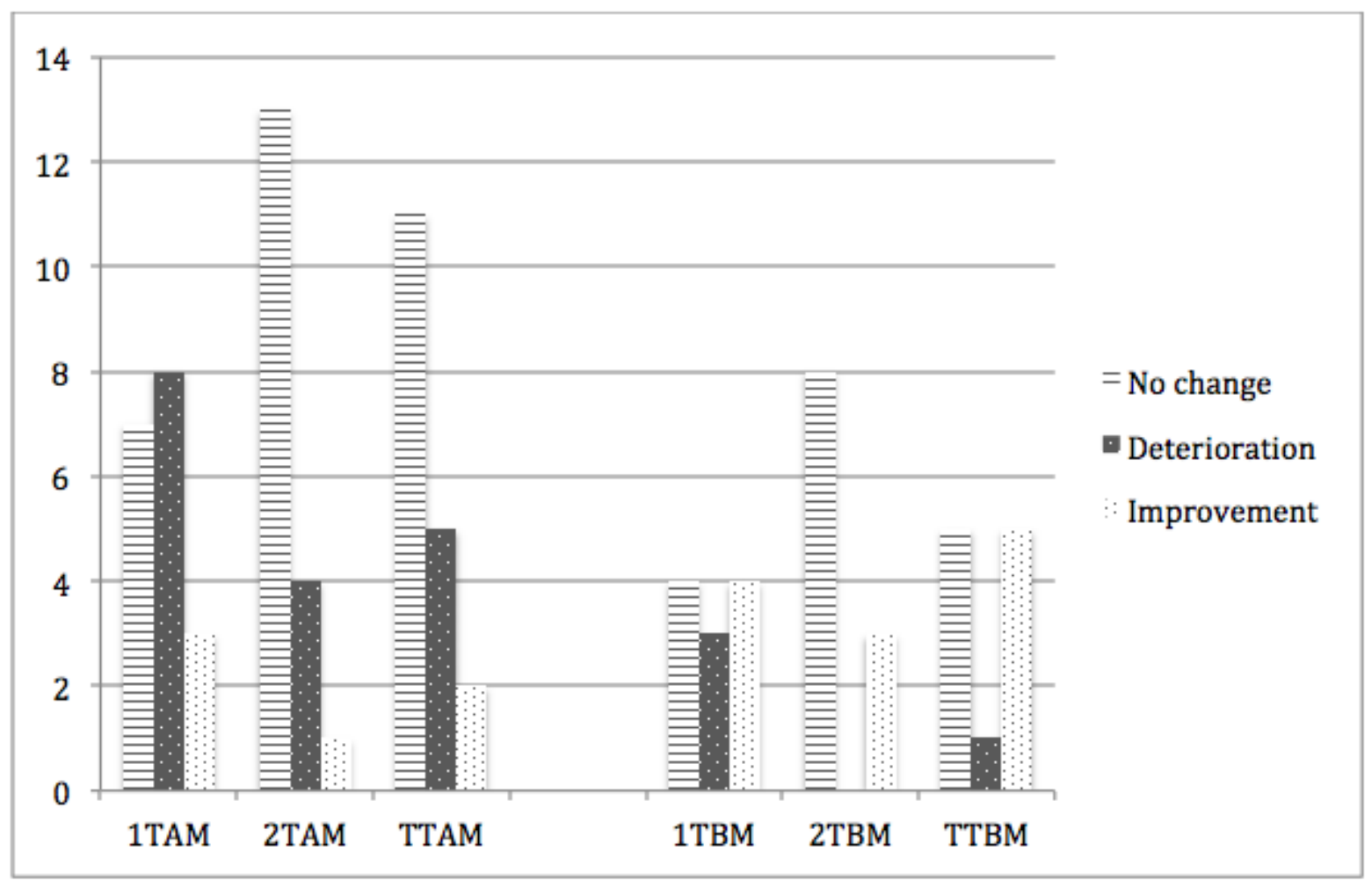

Figure 4: Participant score development over the three tests: comparison of Pre-test to Mid-test (1T), Mid-test to Post-test (2T) and Post-test to Pre-test (TT) for four evaluation items. Letters A and B represent Groups A and B respectively. Letter $M$ refers to meaning-related translation competences. (Group A: $n=18$, Group B: $n=11$ )

Figure 4 displays significantly different score development tendencies in Groups A and B. While in Group A half of the participants $(n=9)$ scored lower in the Mid-test than in the Pre-test (1TAM), in Group B this was the case for only three participants $(27.27 \%)$ (1TBM). The comparison between the results in the Post-test with those in the Mid-test (2TAM and 2TBM) indicates that the same proportions scored the same in both groups $(72.72 \%$ in Group A and 72.22\% in Group B); however, the remaining participants in Group B ( $\mathrm{n}=3,27.27 \%$ ) scored higher, while in Group A only one participant did. The most remarkable difference between the two groups can be noted in the comparison between the Pre-test and the Post-test (TTAM and TTBM): while the majority of the participants in Group A $(n=16,88.88 \%)$ scored either lower $(n=5,27.77 \%)$ or the same $(n=11,61.11 \%)$, in Group B almost half of the students scored higher $(n=5,45.45 \%)$ and only one participant scored lower $(9.09 \%)$.

This analysis shows that the score development in terms of meaning-related items evaluation is much more substantial and positive in Group B. Crucially, this is the only domain within which the score development tendencies between the two groups are reversed. Specifically, in Group A, 50\% of the students saw their results deteriorate in the Mid-test, after having done the peer feedback activities, with respect to the Pre-test. In Group B, however, none of the participants received worse results and nearly one third (27.27\%) scored higher in the Posttest with respect to the Mid-test, that is, immediately after their peer feedback activities.

A closer analysis of the score development over all the tests in Group B showed that the participants' results improved in terms of almost all meaning-related items. Specifically, the students' scores on the translation of It's [this blasted puberty], give a bodyguard's once-over and work her way through improved over the three tests; however, the translation of a mane [of tight blonde curls] deteriorated. 
The results presented above suggest no clear-cut trends in terms of participants' score development patterns with respect to formal linguistic and meaning-related evaluation items. Strikingly, the combination of the timing of peer feedback activities and types of evaluation items has resulted in substantially different score development tendencies within Groups A and B. Specifically, Group A performed best on the formal linguistic items and worst on the meaning-related items in the test that was conducted immediately after having done the peer feedback activities. In contrast, Group B scored best on the meaning-related items and worst on the formal linguistic items in the test organised after having done the peer feedback activities.

In addition, scores on formal linguistic items developed in a non-linear way regardless of the timing of peer feedback activities. The comparison of the score development with a focus on the formal linguistic evaluation items generated mixed tendencies: i.e. a relatively high number of participants with improved results in the Midtest with respect to the Pre-test, a similarly high number of participants with deteriorated or unchanged results in the Post-test with respect to the Mid-test, and a dominant number of participants with unchanged results in the Post-test with respect to the Pre-test. Both groups displayed these score development tendencies regardless of when they were engaged in peer feedback activities. This finding stands in contrast to the conclusions reported in the literature on the effects of peer feedback, but the limited number of participants and items in the present study does not allow us to make any definitive claims.

Importantly, our experiment emphasised a number of elements that should be taken into account in future studies. First, the materials used in the tests and peer-to-peer activities should contain comparable stylistic and genre features so that students are assessed in terms of the competences that they are asked to practise during peer feedback activities. This was not the case in the present study as the participants practised popular science translation and the text used in the tests was an excerpt from a literary work.

The number of meaning-related pre-selected evaluation items is another point that needs to be considered. In our experiment, the balance of the ten pre-selected evaluation items was in favour of formal linguistic items (six versus four). In order to arrive at a clearer understanding of how peer feedback activities affect the generation and negotiation of meaning, future experiment designs should contain a more balanced number of form and meaningrelated evaluation items. 


\section{References}

Babych, B., Hartley, A., Kageura, K., Thomas, M., \& Utiyama, M. (2012). MNH-TT: a collaborative platform for translator training. Presented at Translating and the Computer, 34, London, UK.

Berg, E. C. (1999). The effects of trained peer response on ESL students' revision types and writing quality. Journal of Second Language Writing, 8(3), 215-241.

Desjardins, R. (2011). Facebook me!: Initial insights in favour of using social networking as a tool for translator training. Linguistica Antverpiensia, New Series-Themes in Translation Studies, 10, 175-196.

Finn, G. M., \& Garner, J. (2011). Twelve tips for implementing a successful peer assessment. Medical teacher, $33(6), 443-446$.

Flynn, E. A. (1982). Freedom, restraint and peer group interaction. Paper presented at the Annual Meeting of the Conference on College Composition and Communication, San Francisco, California, USA.

Gambier, Y. (2012). Teaching translation / Training translators. In: Y. Gambier \& L. van Doorslaer (eds.), Handbook of Translation Studies, Volume 3, 163-171. Amsterdam: J. Benjamins.

Gonzáles Davies, M. (2004). Multiple Voices in the Translation Classroom. Amsterdam: J. Benjamins.

Huertas Barros, E. (2011). Collaborative learning in the translation classroom: preliminary survey results. JoSTrans, 16. Retrieved June 9, 2014, from http://www.jostrans.org/issue16/art_barros.php.

Humbley, J., Maylath, B., Mousten, B., Vandepitte, S. \& Veisblat, L. (2005). Learning localization through transAtlantic collaboration. In: George F. Hayhoe (ed.), Professional Communication Conference Proceedings, 2005. IPCC 2005. IEEE International. Proceedings. New York: IEEE. 578-595.

Kenny, M. A. (2008). Discussion, cooperation, collaboration: The impact of task structure on student interaction in a Web-based translation exercise module. The Interpreter and Translator Trainer, 2(2), 139-16.

Kiraly, D. (2001). Towards a constructivist approach to translator education. Quaderns: Revista de traducció, 6, $50-53$.

Leki, I. (1990). Potential problems with peer responding in ESL writing classes. CATESOL journal, 3(1), 5-19.

Mangelsdorf, K., \& Schlumberger, A. (1992). ESL student response stances in a peer-review task. Journal of Second Language Writing, 1(3), 235-254.

Miao, Y., Badger, R., \& Zhen, Y. (2006). A comparative study of peer and teacher feedback in a Chinese EFL writing class. Journal of Second Language Writing, 15, 179-200.

Min, H. T. (2005). Training students to become successful peer reviewers. System, 33(2), 293-308.

Min, H. T. (2006). The effects of trained peer review on EFL students' revision types and writing quality. Journal of Second Language Writing, 15(2), 118-141.

Muñoz Martín, R., Gervilla, E., Vargas-Quesada, B., Senso-Ruiz, J., Murillo-Melero, M., Castro-Prietro, M., Olvera-Lobo, M., Robinson, B., Raya, E., Lerma, J. (2007). A professional approach to translator training (PATT). Meta 52(3), 517-528. 
O’Brien, S. (2011). Collaborative translation. In: Y. Gambier \& L. van Doorslaer (eds.), Handbook of Translation Studies, Volume 2, 17-20. Amsterdam: J. Benjamins.

Paulus, T. M. (1999). The effect of peer and teacher feedback on student writing. Journal of Second Language Writing, 8(3), 265-289.

Pavlović, N. (2007). Directionality in Collaborative Translation Processes. Ph.D. thesis. Tarragona: Universitat Rovira i Virgili. Retrieved June 9, 2014, from http://www.tesisenxarxa.net/TDX-1210107-172129/

Risku, H. \& Dickinson, A. (2009): Translators as Networkers. The Role of Virtual Communities. Hermes, 42, 4970 .

Scardamalia, M. (2001). Big change questions: Will educational institutions, within their present structures, be able to adapt sufficiently to meet the needs of the information age? Journal of Educational Change, 2, 171-176.

Starke-Meyerring, D. (2008). Cross-boundary knowledge making in globally networked learning environments. SUNY Center for Online Collaborative Learning (COIL), Purchase, NY.

Strijbos, J. W., \& Sluijsmans, D. (2010). Unravelling peer assessment: Methodological, functional, and conceptual developments. Learning and Instruction, 20(4), 265-269.

Swain, M., Brooks, L., and Tocalli-Beller, A. (2002). Peer-peer dialogue as a means of second language learning. Annual Review of Applied Linguistics, 22, 171-185.

Tang, G. M., \& Tithecott, J. (1999). Peer response in ESL writing. TESL Canada Journal, 16, 20-38.

Tudge, J.R.H. (1990). Vygotsky, the zone of proximal development, and peer collaboration: Implications for classroom practice. In L.C. Moll (Ed.), Vygotsky and education: Instructional implications and applications of sociohistorical psychology (pp. 155-172). Cambridge: Cambridge University Press.

Vandepitte, S., Mousten, B., Maylath, B., Isohella, S., Musacchio, M.T. \& Palumbo, G. (2015). Translation Competence Research Data in Multilateral International and Interprofessional Collaborative Learning. Chapter 9. Ying Cui and Wei Zhao (eds.), Teaching Language Translation and Interpretation: Methods, Theories, and Trends. Hershey, PA: IGI Global.

Van Steendam, E., Rijlaarsdam, G., Sercu, L., \& Van den Bergh, H. (2010). The effect of instruction type and dyadic or individual emulation on the quality of higher-order peer feedback in EFL. Learning and Instruction, 20(4), 316-327.

van Zundert, M., Sluijsmans, D., \& Van Merriënboer, J. (2010). Effective peer assessment processes: Research findings and future directions. Learning and Instruction, 20(4), 270-279.

Villamil, O. S., \& De Guerrero, M. (1998). Assessing the impact of peer revision on L2 writing. Applied Linguistics, 19(4), 491-514.

Vygotsky, L.S. (1978). Mind in Society: The Development of Higher Psychological Processes. Cambridge: Harvard University Press.

Vygotsky, L.S. (1986). Thought and Language. Cambridge, MA: The MIT Press.

Wells, G. (1999). Dialogic Inquiry: Toward a Sociocultural Practice and Theory of Education. Cambridge: Cambridge University Press. 
Zili, D. (2009). An Empirical Study on Campus Internet-based Peer Review and Interactive Translation. Chinese Translators Journal, 3, 44-49, 95-96. 


\section{Appendix A}

\begin{tabular}{|c|c|c|c|c|c|c|c|c|c|}
\hline Timeline & Week 1 day 1 & \multicolumn{3}{|l|}{ Weeks 1-3 } & Week 4 Day 1 & \multicolumn{3}{|l|}{ Weeks 4-6 } & Week 7 \\
\hline & & \multicolumn{3}{|c|}{ Experiment Group: Group A } & & \multicolumn{3}{|c|}{ Experiment Group: Group B } & \\
\hline Tests & Pre-test & & & & Mid-test & & & & Post-test \\
\hline \multirow[t]{2}{*}{ Group $\mathbf{A}$} & $\begin{array}{l}\text { Measurement } \\
\text { of translation } \\
\text { competences }\end{array}$ & \multicolumn{3}{|c|}{$\begin{array}{l}\text { Becoming familiar with and explicit } \\
\text { application of student peer review and } \\
\text { revision competences }\end{array}$} & $\begin{array}{l}\text { Measurement of } \\
\text { translation } \\
\text { competences }\end{array}$ & \multicolumn{3}{|c|}{$\begin{array}{l}\text { No explicit application of student peer } \\
\text { review and revision competences }\end{array}$} & $\begin{array}{l}\text { Measurement of } \\
\text { translation } \\
\text { competences }\end{array}$ \\
\hline & & $\begin{array}{l}\text { 1. Translation } \\
\text { of a text }\end{array}$ & $\begin{array}{l}\text {. Peer } \\
\text { review and } \\
\text { revision }\end{array}$ & $\begin{array}{l}\text { 3. Follow } \\
\text { up of peer } \\
\text { review } \\
\text { and } \\
\text { revision }\end{array}$ & & & & & \\
\hline \multirow[t]{2}{*}{ Group B } & $\begin{array}{l}\text { Measurement } \\
\text { of translation } \\
\text { competences }\end{array}$ & \multicolumn{3}{|c|}{$\begin{array}{l}\text { Becoming familiar with student peer review } \\
\text { and revision competences } \\
\text { No explicit application }\end{array}$} & $\begin{array}{l}\text { Measurement of } \\
\text { translation } \\
\text { competences }\end{array}$ & \multicolumn{3}{|c|}{$\begin{array}{l}\text { Explicit application of student peer review } \\
\text { and revision competences }\end{array}$} & $\begin{array}{l}\text { Measurement of } \\
\text { translation } \\
\text { competences }\end{array}$ \\
\hline & & & & & & $\begin{array}{l}\text { 1. } \\
\text { Translation } \\
\text { of a text }\end{array}$ & $\begin{array}{l}\text { 2. Peer } \\
\text { review and } \\
\text { revision }\end{array}$ & $\begin{array}{l}\text { 3. Follow up } \\
\text { of peer } \\
\text { review and } \\
\text { revision }\end{array}$ & \\
\hline
\end{tabular}




\section{Appendix B}

Test items are represented by the keywords in bold.

\section{Pre-Test}

Artemis rubbed his temples.

'It's this blasted puberty, Butler. Every time I see a pretty girl, I waste valuable mind space thinking about her. That girl at the restaurant for instance. I've glanced in her direction a dozen times in the past few minutes.'

Butler gave the pretty girl in question an automatic bodyguard's once-over.

She was twelve or thirteen, did not appear to be armed and had a mane of tight blonde curls. The girl was studiously working her way through a selection of petits fours while a male guardian, perhaps her father, read the paper.

\section{Mid-Test}

'It's this rotten puberty, Ron.'

Harry rubbed his temples.

'Every time I see a chick, I waste valuable mind space thinking about her. The girl at that cafeteria for instance. I've glanced in her direction dozens of times in the past few minutes.'

Ron first hesitated but then gave the chick in question an automatic bodyguard's once-over.

She was thirteen or fourteen, did not appear to be armed and had a mane of loose blonde curls. The girl was carefully working her way through a selection of petits fours while a male guardian, perhaps her grandfather, read the paper.

\section{Post-Test}

The girl was eleven or twelve and had a mane of tight black curls. She was diligently working her way through a selection of petits fours while a male guardian, perhaps her brother, read a magazine.

'Every time I see a pretty girl, I waste valuable mind space thinking about her. That babe at the bar for instance. It's this bloody puberty, Tim. I've been glancing in her direction a dozen times in the last few minutes.'

Nick rubbed his temples.

Tim gave the babe in question an automatic bodyguard's once-over. She did not seem to be armed. 